\title{
MEASUREMENT OF MUCOCILIARY CLEARANCE FROM THE LOWER RESPIRATORY TRACT OF NORMAL DOGS
}

\author{
P.B. Wood, M.B., ${ }^{\star}$ E. Nagy, M.D., $\nmid$ F.G. Pearson, M.D., $\neq$ and S. RaE $§$
}

\section{INTRODUCTION}

NumERous FACTORS and pathological processes can affect the mucociliary apparatus. Movement of the mucus blanket may be impaired as a result of abnormal function of the cilia or changes in the composition or characteristics of the mucus.

Studies of this function were first based on direct visualization of the rate of movement of a variety of particles and substances placed on the mucosal surface. Ingenious preparations have been used in which the intact mucosa could be viewed through windows. Since the mucociliary apparatus is extremely sensitive to exogenous and endogenous influences much of this work has been condemned as being quite unphysiological. ${ }^{1}$ An effort was therefore made to view the mucosa indirectly.

Togio et al. ${ }^{2}$ used carbon particles between $40 \mu$ and $70 \mu$ in diameter labelled with ${ }^{131} \mathrm{I}$ and ${ }^{198} \mathrm{Au}$. Although the load moving capability of cilia is high their slow clearances have been attributed to the relatively large size of the particles they used.

Proctor and Wagner ${ }^{3}$ used a radioactive indicator and followed its movement with serial scans. Microdroplets of a solution of sodium iodide labelled with ${ }^{131} \mathrm{I}$ and suspensions of micro- or macro-aggregated human serum albumen labelled with ${ }^{131} \mathrm{I}$, were used. Dispersion and streaming of the microdroplets, however, made accurate determinations of transit rates difficult, although mean transit rates were the same for the iodine solution and for the albumin suspensions.

In 1968, Nadel and others introduced a technique of bronchography using powdered tantalum. ${ }^{4} \mathrm{~A}$ fine, non-toxic powder could be introduced to show airways in great detail. The technique described by $\mathrm{Nadel}^{5}$ requires the use of a polyvinyl catheter introduced under fluoroscopic control into each main stem bronchus and into or alongside each segmental bronchus to be outlined. This has been used as a basis for clearance studies by Edmunds et al.$^{6}$ and there are reasons for considering this to be the preferred method of measuring mucociliary transport. However, we have been worried that the trauma to the bronchial mucosa produced by this method of tantalum delivery might significantly delay mucociliary clearance. Hilding and Hilding in 1962 first showed in vitro that the mucociliary apparatus was extremely sensitive to trauma and "even light stroking disrupts cilia, stops mucus transport and induces desquamation of ciliated cells".?

"Research Fellow, Department of Surgery, University of Toronto.

†Research Fellow, Department of Surgery, University of Toronto.

$\$$ Associate Professor, Department of Surgery, University of Toronto and Head, Division of Thoracic Surgery, Toronto General Hospital.

\$Research Assistant, Department of Surgery, University of Toronto. 
Because of the possibility that the trauma of bronchial catheterization caused delay in tantalum clearance, an alternative method of tantalum delivery was designed. The present report is concerned with clearance studies in normal dogs and the impact on clearance times of this modification.

\section{Materials ANd Methods}

Dogs were divided into three groups designed to determine the effects of trauma from bronchial catheterization on mucociliary transport. In each group tantalum was introduced by a different method.

Method A In one group, Nadel's method of delivery was used, ${ }^{5}$ the only modification being that weighed amounts of tantalum were directed into each lung. Five grams of tantalum were used, divided into $2.8 \mathrm{gm}$ for the right lung and $2.2 \mathrm{gm}$ for the left, in accordance with the relative sizes of the lungs. ${ }^{8}$

Under general anaesthesia (thiopentone $20 \mathrm{mg} / \mathrm{Kg} \mathrm{I.V.)} \mathrm{a} \mathrm{bronchoscope} \mathrm{was}$ introduced into each main bronchus and a modified Kifa catheter was introduced into or alongside the segmental bronchus to be outlined. Tantalum powder was delivered through the catheter from an atomizer using a compressed air source.

Method B In this group tantalum was introduced without any physical contact or potential injury to the bronchial mucosa. Under thiopentone anaesthesia a soft rubber endotracheal tube was introduced into the trachea to a point about $2 \mathrm{~cm}$ from the carina. The animal was then respired 20 times per minute on a Harvard respirator set with a tidal volume of $300 \mathrm{cc}$. A further $200 \mathrm{cc}$ of air was introduced during each inspiration by an atomizer containing $5 \mathrm{gm}$ of tantalum. The atomizer was located on an agitator to ensure an even distribution of the particles. The air jet containing a fine cloud of tantalum was directed through a fine catheter to a point $2 \mathrm{~cm}$ from the end of the endotracheal tube (Figure 1).

Tantalum can similarly be introduced through a tracheal divider although, like bronchial catheterization, this is also open to the objection that it traumatizes the bronchial mucosa. However, contact with the mucosa is limited to the trachea and proximal $1.5 \mathrm{~cm}$ of the left main bronchus and the use of the divider enables exact weights of tantalum to be delivered to the bronchial tree on each side. Of the 16 studies performed using method B, four were produced with an endotracheal tube and 12 with a tracheal divider. $2.8 \mathrm{gm}$ of tantalum powder was introduced through the right side of the divider and $2.2 \mathrm{gm}$ through the left.

Method $C$ In a final group of dogs the introduction of tantalum combined methods A and B in opposite lungs of the same dog, to allow direct comparison of the two methods in the same dog. After the production of a bronchogram by method B, the left or right bronchial tree was lightly traumatized with a modified Kifa catheter under fluoroscopic control, in a manner judged likely to simulate the trauma produced by method $\mathrm{A}$. Where more than one such study was performed in the same dog, the side lightly traumatized was alternated from study to study. A period of at least five days was always left between studies.

For all three methods healthy dogs of $18-22 \mathrm{Kg}$ were used. Tantalum powder with an average mass diameter of $5 \mu$ was used throughout. The atomizer was grounded electrically to prevent sparks, because tantalum will burn under appropriate conditions. Clearance of tantalum from airways was studied by repeating 


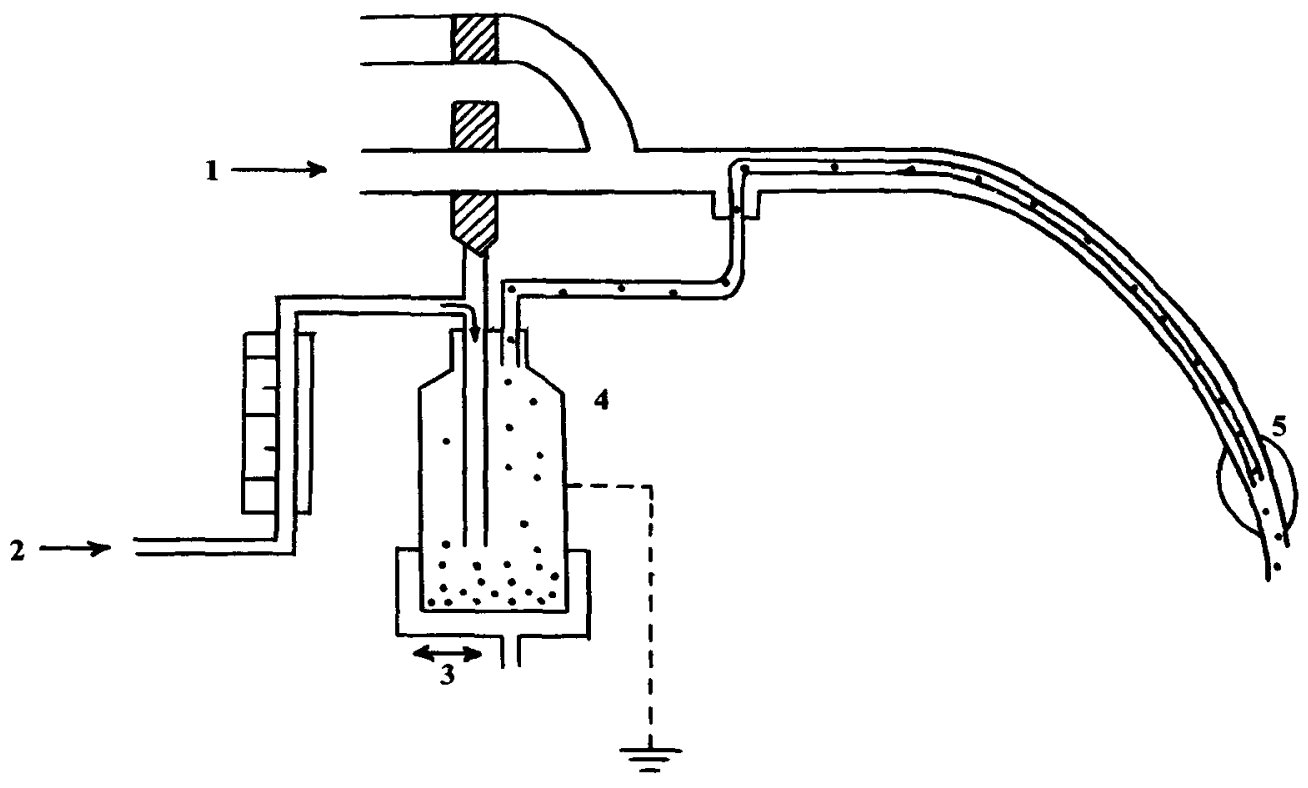

Inspiration

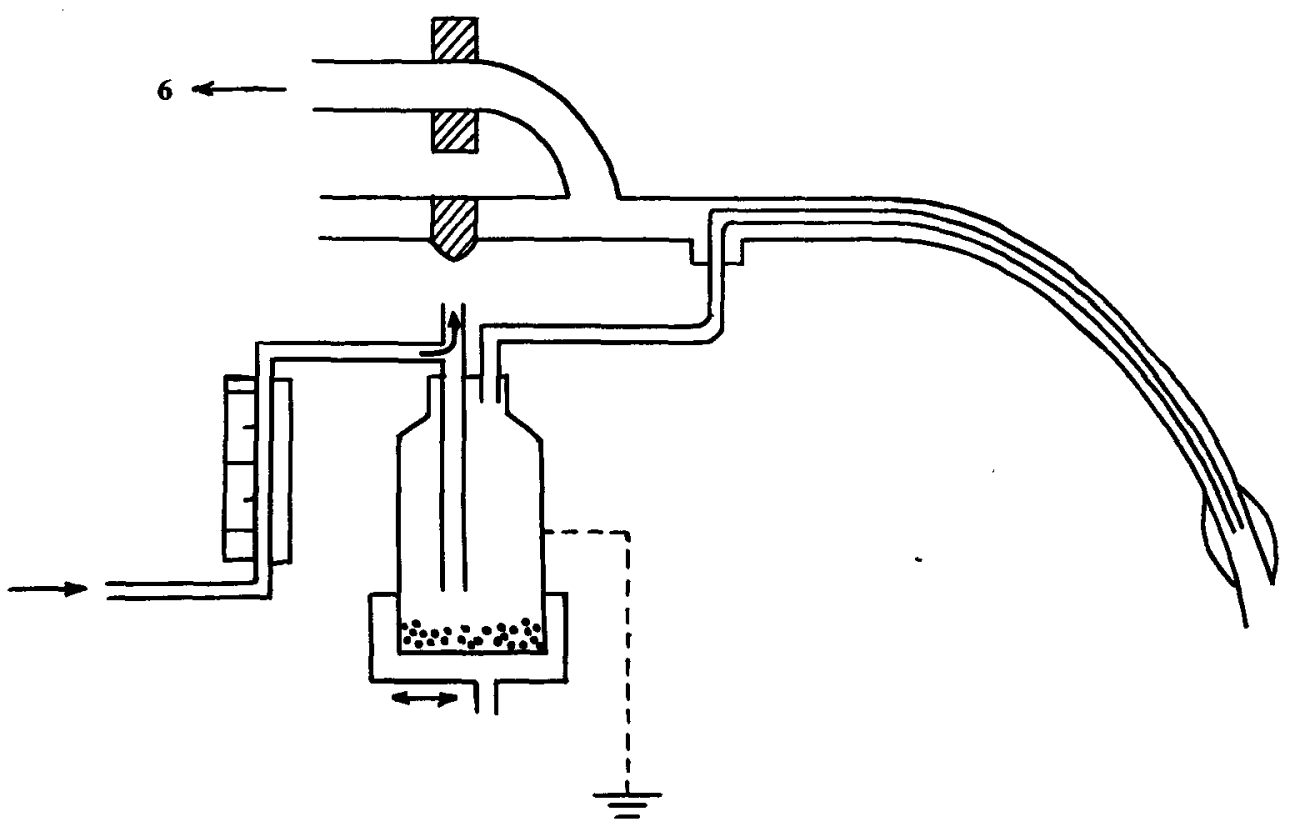

Expiration

FIGURE 1. Diagram showing method of tantalum delivery without bronchial catheterization (Method B).

1. Harvard respirator inspiratory inlet, 2. Compressed air source \& flowmeter, 3. Agitator, 4. Atomizer, 5. Endotracheal tube or tracheal divider, 6. Expiratory outlet - Harvard respirator. 


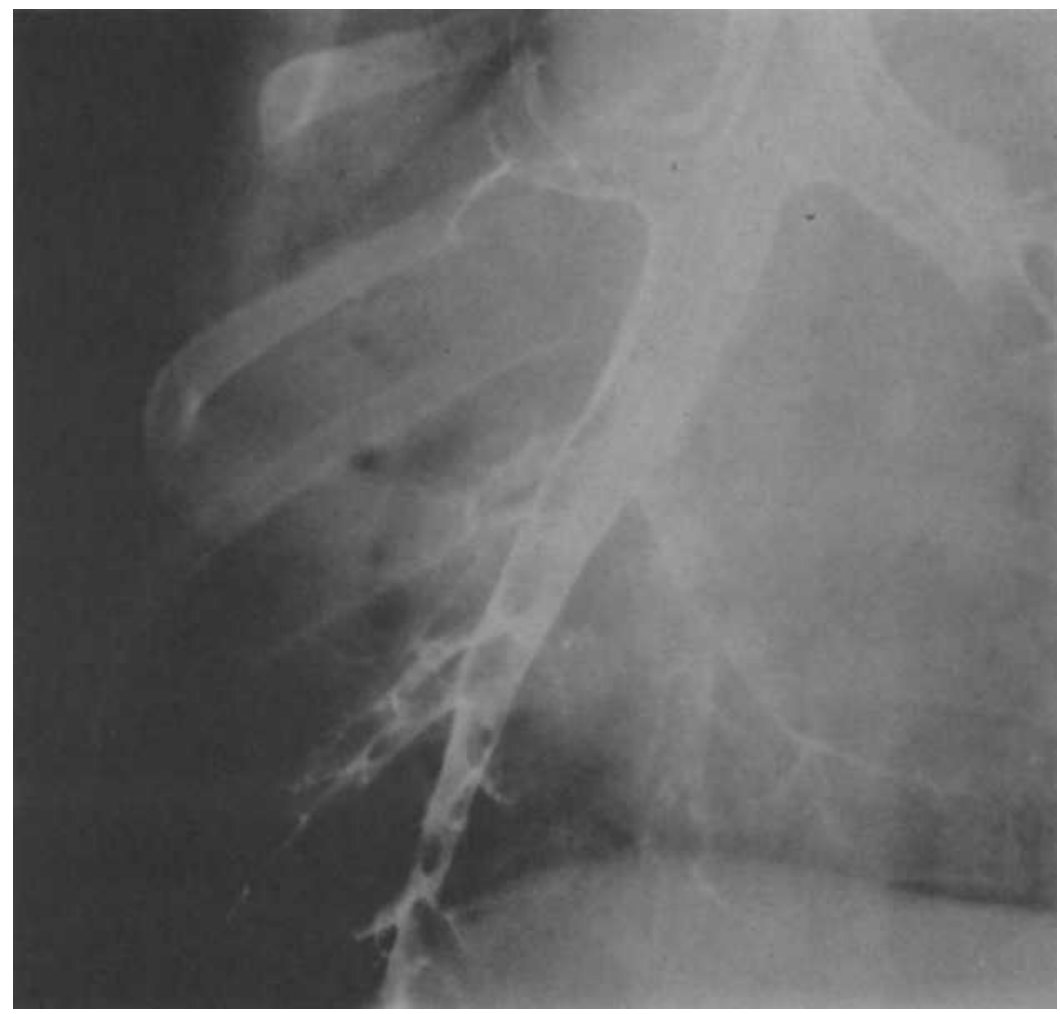

FIgURE 2. Radiographs at 2-hourly intervals. 2a. Initial bronchogram.

postero-anterior radiographs of the chest at 2-, 4-, 6- and 24-hour intervals after bronchography and without further anaesthesia.

\section{Interpretation of Results}

The quantities of tantalum powder remaining in each side of the bronchial tree were determined for each chest radiography by comparison with a standard set of bronchograms in which the amount of tantalum present was graded from 1 to 10 . Thus the residual tantalum was graded out of a possible maximum of 10 . All the assessments were made independently by the same three observers. Their grades were averaged and multiplied by 10 to give an approximate percentage of residual tantalum.

Clearance from the proximal $1.5 \mathrm{~cm}$ of each main bronchus was disregarded because of the possible artefact at this level due to the trauma of the tracheal divider.

Tantalum labelled "puddles" of mucus were seen in many studies and were always disregarded in assessing clearance grades since there is no evidence that puddling represents any abnormality of mucociliary function. "Puddling" or "pooling"6 is the occurrence of plugs of mucus heavily labelled with tantalum in dependent bronchi. It occurs due to gravitational effects during recovery from anaesthesia when the dog is lying on its side. It undoubtedly represents a failure of the 


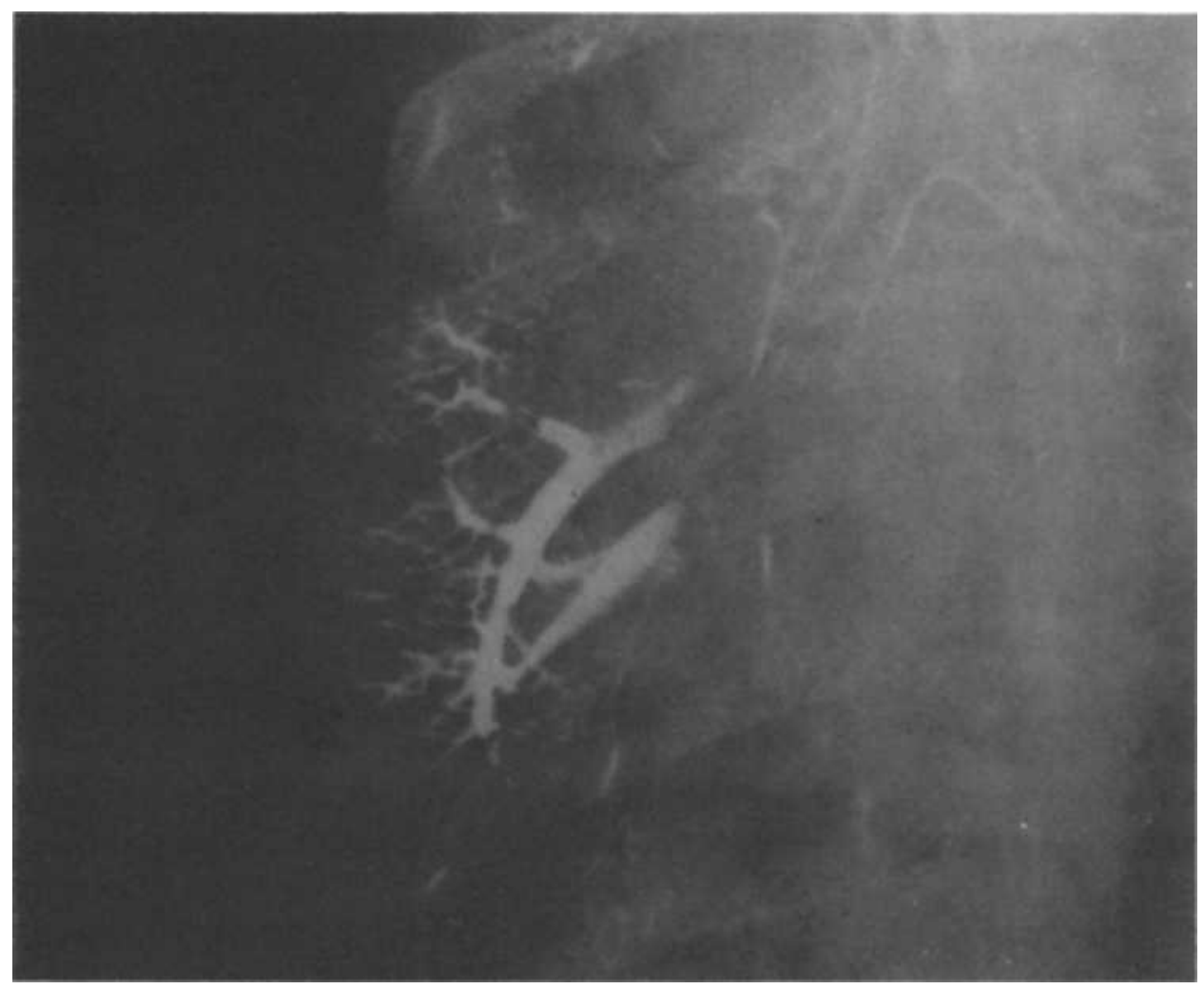

FIGURE 2b. 2 hours later "puddling" has developed (mucus heavily stained with tantalum) in the middle lobe bronchus which was not outlined in the initial film. The animal was lying on its right side during recovery from anaesthesia.

mucociliary apparatus but we regard it as a normal apparatus being presented with abnormal quantities of mucus due to a constant gravitational influence. Adjacent areas are cleared in a normal manner. The plugs themselves are only cleared by coughing and may lodge temporarily on the contralateral side prior to expectoration. Puddling can progress to alveolarization of tantalum, presumably during coughing and as distal trapped air is absorbed (a process shown in Figures 2a, b, and c). In the alveoli, tantalum is cleared extremely slowly by the reticuloendothelial system ${ }^{10}$ and some deposits remain in pulmonary lymphatics and lymph nodes for many months. Alveolarization is never produced by the initial insufflation of tantalum.

Small bronchi of less than $1 \mathrm{~mm}$ in diameter were not usually outlined, but occasionally the lumen became solidly packed with tantalum during insufflation. This phenomenon was considered due to the method of insufflation and appears to impose an abnormal load on the mucociliary apparatus since such packed tantalum is cleared extremely slowly. For these reasons the clearance of solid plugs of tantalum in small bronchi was not considered in the grading.

By disregarding "puddling" and small "bronchial plugs" our assessments vary 


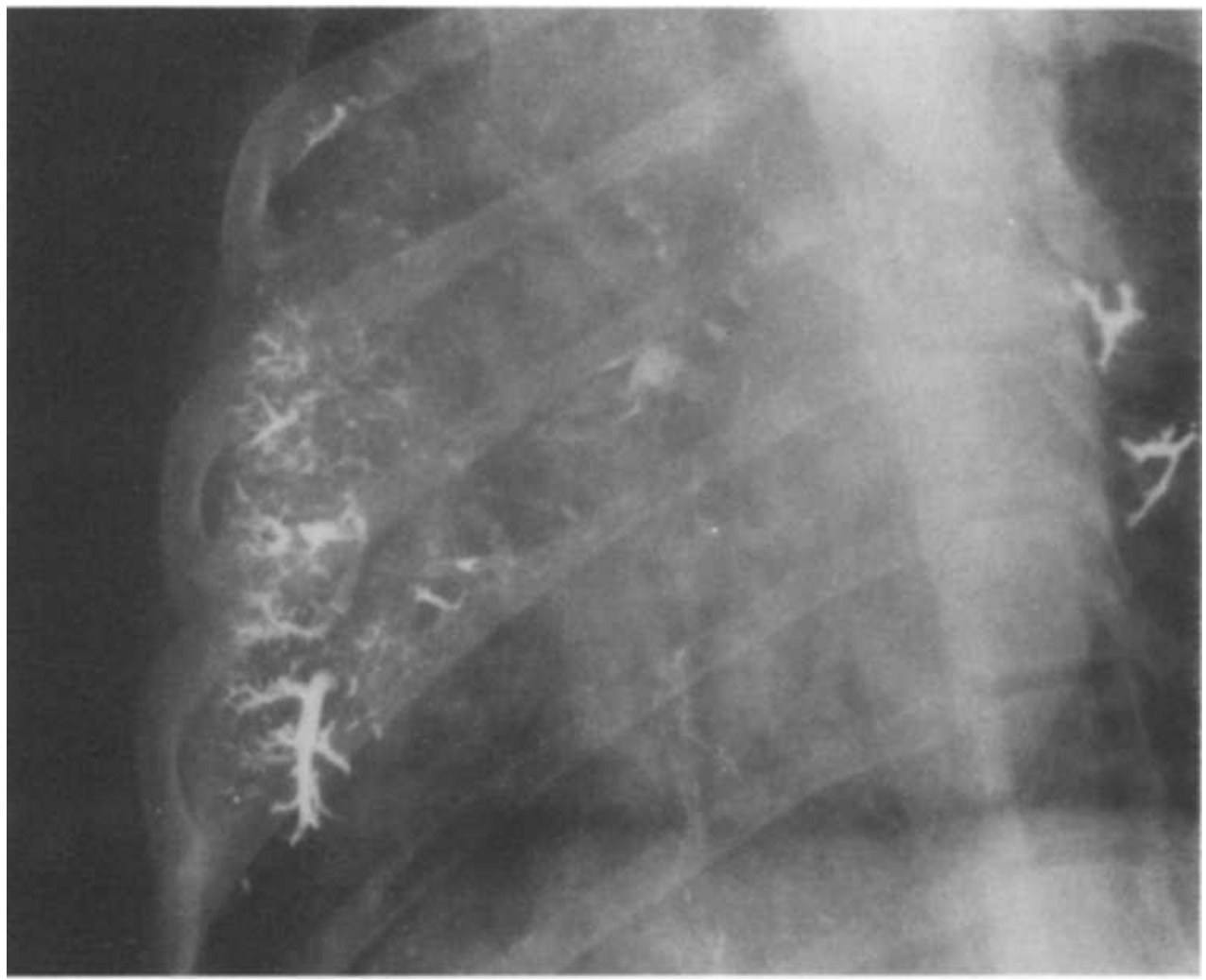

Figure 2c. After 4 hours "puddling" has progressed to "alveolarization". Plugs coughed from the right have lodged temporarily on the left (arrowed).

from those of Edmunds et al. ${ }^{6}$ who only gave a clearance rating of zero "when no visible contrast remained in the airways".

\section{RESUlts}

Using Nadel's technique of endobronchial catheterization to deposit tantalum (method A), an average of 23 per cent of insufflated tantalum remained at two hours. With method B where bronchial catheterization was avoided an average of only 9 per cent remained at two hours. The differences at 4, 6, and 24 hours are more striking. These results are illustrated in Table I.

With method A only 6 of 23 studies ( 25 per cent) showed complete clearance of tantalum at two hours. Using method B, 9 of 16 ( 50 per cent) had cleared completely at two hours. After four hours, 7 of 23 ( 30 per cent) had cleared completely with method A, whilst 13 of 16 ( 80 per cent) had cleared completely with method B.

A simultaneous comparison of the two methods is available in method C. Using method B to produce the bronchogram, one side of the bronchial tree was traumatized to simulate endobronchial catheterization (method A). Trauma caused a 
TABLE I

Average Percentage of Remaining Tantalum, after Tantalum Bronchography in Normal Dogs

\begin{tabular}{|c|c|c|c|c|c|c|}
\hline \multirow[b]{2}{*}{$\begin{array}{l}2 \text { hrs. } \\
4 \text { hrs. } \\
6 \text { hrs. } \\
24 \text { hrs. }\end{array}$} & \multicolumn{2}{|c|}{$\begin{array}{l}\text { Method A } \\
\text { With } \\
\text { Bronchial Catheterization }\end{array}$} & \multicolumn{2}{|c|}{$\begin{array}{c}\text { Method B } \\
\text { Without } \\
\text { Bronchial Catheterization }\end{array}$} & \multicolumn{2}{|c|}{$\begin{array}{l}\text { From Edmunds et al. } 6 \\
\text { p. 134, Table 2, With } \\
\text { Bronchial Catheterization }\end{array}$} \\
\hline & $\begin{array}{r}\mathrm{R} . \\
20 \\
14 \\
5 \\
3 \\
23 \mathrm{de} \\
\quad \text { ir }\end{array}$ & $\begin{array}{l}\mathrm{L} . \\
23 \\
17 \\
7 \\
1 \\
\text { tions } \\
\text { s }\end{array}$ & $\begin{array}{c}\mathrm{R} . \\
4 \\
0 \\
0 \\
0 \\
16 \mathrm{de} \\
\text { in }\end{array}$ & $\begin{array}{l}\text { L. } \\
9 \\
2 \\
1 \\
0 \\
\text { ations } \\
\text { gs }\end{array}$ & $\begin{array}{l}\mathrm{R} . \\
30 \\
26 \\
21 \\
8 \\
6 \mathrm{~d}\end{array}$ & $\begin{array}{c}\mathrm{L} . \\
32 \\
32 \\
28 \\
5 \\
\text { tions } \\
\text { s }\end{array}$ \\
\hline
\end{tabular}

TABLE II

Average Percentage of Remaining

Tantalum AfTer Tantalum Insufflation

WITHOUT BRONCHIAL CATHETERIZATION

Then Light Trauma to One Side (METHOD C)

\begin{tabular}{rcc} 
& $\begin{array}{c}\text { Traumatized } \\
\text { Side }\end{array}$ & $\begin{array}{c}\text { Non-traumatized } \\
\text { Side }\end{array}$ \\
\hline 2 hours & 30 & 4 \\
4 hours & 14 & 1 \\
6 hours & 9 & 0 \\
24 hours & 2 & 0 \\
& 17 determinations in 8 normal dogs
\end{tabular}

considerable delay in clearance. The clearance rates seen in these dogs are shown in Table II.

Figures $3 \mathrm{a}, \mathrm{b}$, and $\mathrm{c}$ show a typical series of radiographs taken at 2-hourly intervals following the production of a bronchogram by bronchial catheterization (method A). Considerable residual tantalum is visible in the 2- and 4-hour films. The relative delay on the left might be interpreted as a result of relatively greater trauma to that side during introduction of the tantalum.

Figure 4 shows a bronchogram typical of those produced without bronchial catheterization - method B. Tantalum was insufflated through an endotracheal tube. Two hours after insufflation the tantalum has completely cleared. Figure 5 shows a bronchogram produced by the same method through a tracheal divider $2.8 \mathrm{gm}$ on the right and $2.2 \mathrm{gm}$ on the left. Again at two hours, clearance is comexcept for plugs caused by insufflation and visible on the initial film.

Figure 6 shows a typical bronchogram using method C. The initial bronchogram was produced through a tracheal divider by method $\mathrm{B}$, the right bronchial tree was then lightly traumatized. Two hours later considerable tantalum remains on the traumatized side whilst clearance is almost complete from the left.

\section{Discussion}

The observation that mucociliary clearance is slowed by the trauma of bronchial catheterization, supports the report of Hilding and Hilding. ${ }^{7}$ Parks et al. ${ }^{9}$ studied 


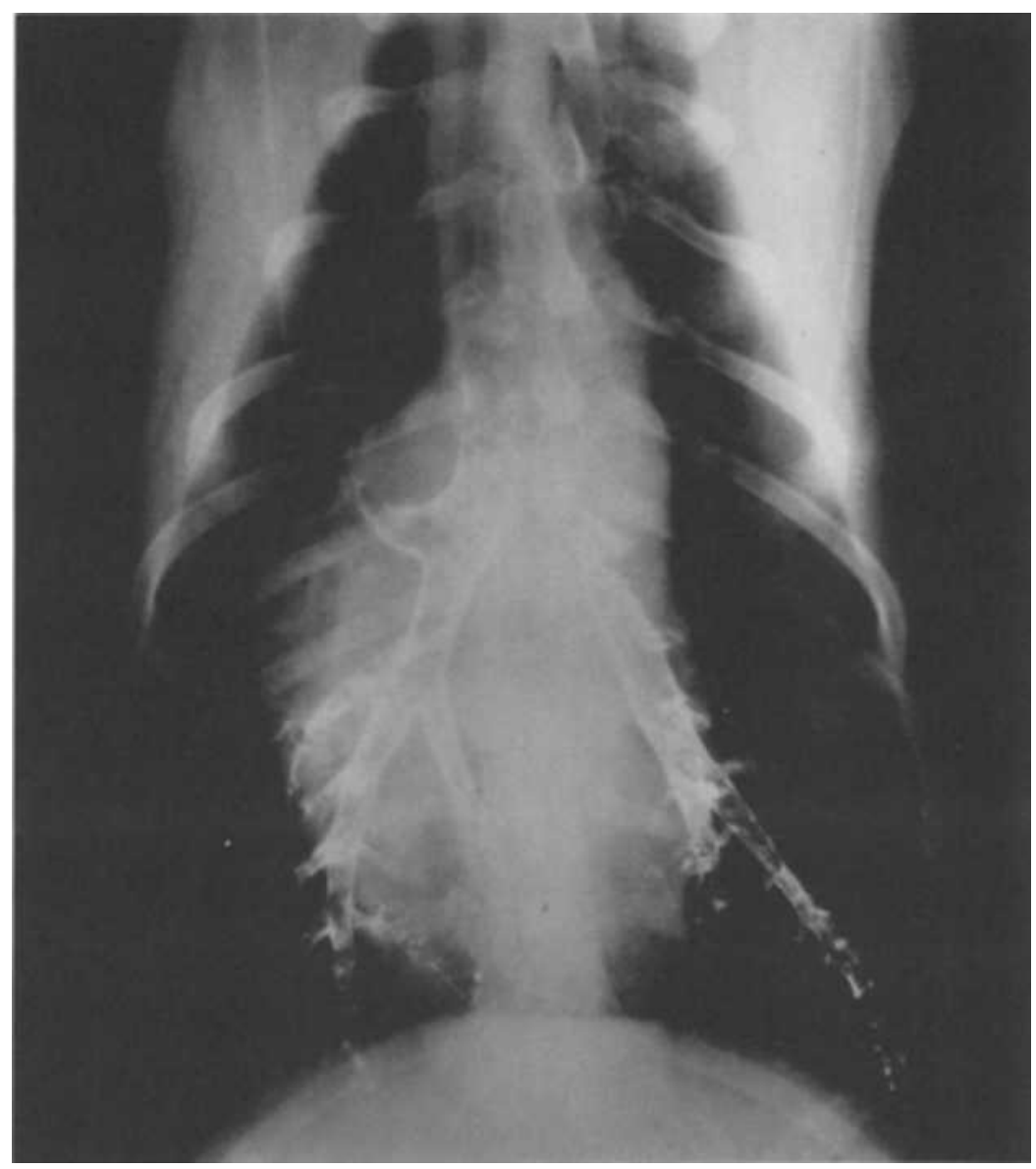

FigUres 3a, b, c. Radiographs at 2-hourly intervals following bronchography by bronchial catheterization (Method A). 3a. Initial Bronchogram.

clearance in normal dogs by using Nadel's technique of bronchial catheterization. They were concerned about the possible artefact due to the trauma of endobronchial catheterization and chose to disregard clearance from the proximal $2 \mathrm{~cm}$ of each main bronchus. The observed clearance rates, however, were significantly slower than those reported in this study using method B. It is assumed that the deleterious effects of trauma due to bronchial catheterization affect the bronchial tree peripheral to the first few centimeters of each main bronchus.

Without bronchial catheterization (method B) the majority of animals completely clear insufflated tantalum within two hours and this clearance time is considered a more accurate definition of the normal value. Variations in hydration, temperature, anaesthesia and minor respiratory tract infections can prolong clearance times but there are no known agents (with the possible exception of some drugs) which speed clearance. A normal clearance time is thus likely to be the fastest time observed and was less than two hours in the present study.

Gravitational puddling (or pooling) has been observed by other authors ${ }^{6}$ but 


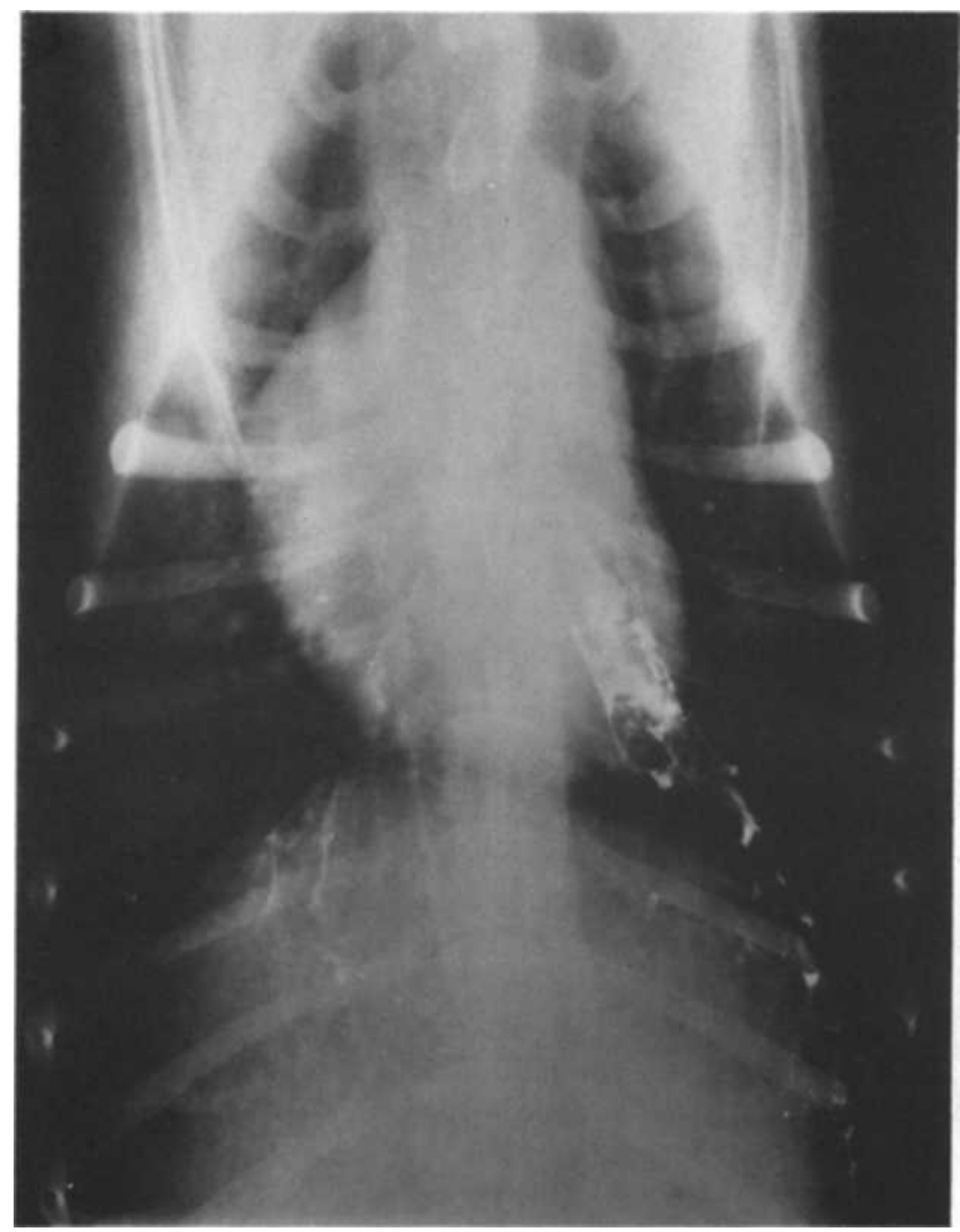

Figure 3b. At 2 hours considerable residual tantalum remains, mainly where the bronchial catheter traumatized the mucosa.

the observation that puddling can progress to alveolarization appears to be unique. This is the only mechanism in this study which leads to tantalum labelled secretions passing peripherally into the alveolar spaces. During recovery from anaesthesia a constant gravitational influence enduring less than two hours (with the animal lying on its side) appears sufficient to produce puddling and subsequent alveolarization in a healthy bronchial tree. This process presumably occurs in humans during prolonged anaesthesia, during recovery from anaesthesia or when immobile in bed. Gross pooling of mucus in dependent bronchi may cause atelectasis and alveolarization may result in dissemination of pathogenic organisms to more peripheral areas of the lung parenchyma. It has been appreciated for some 


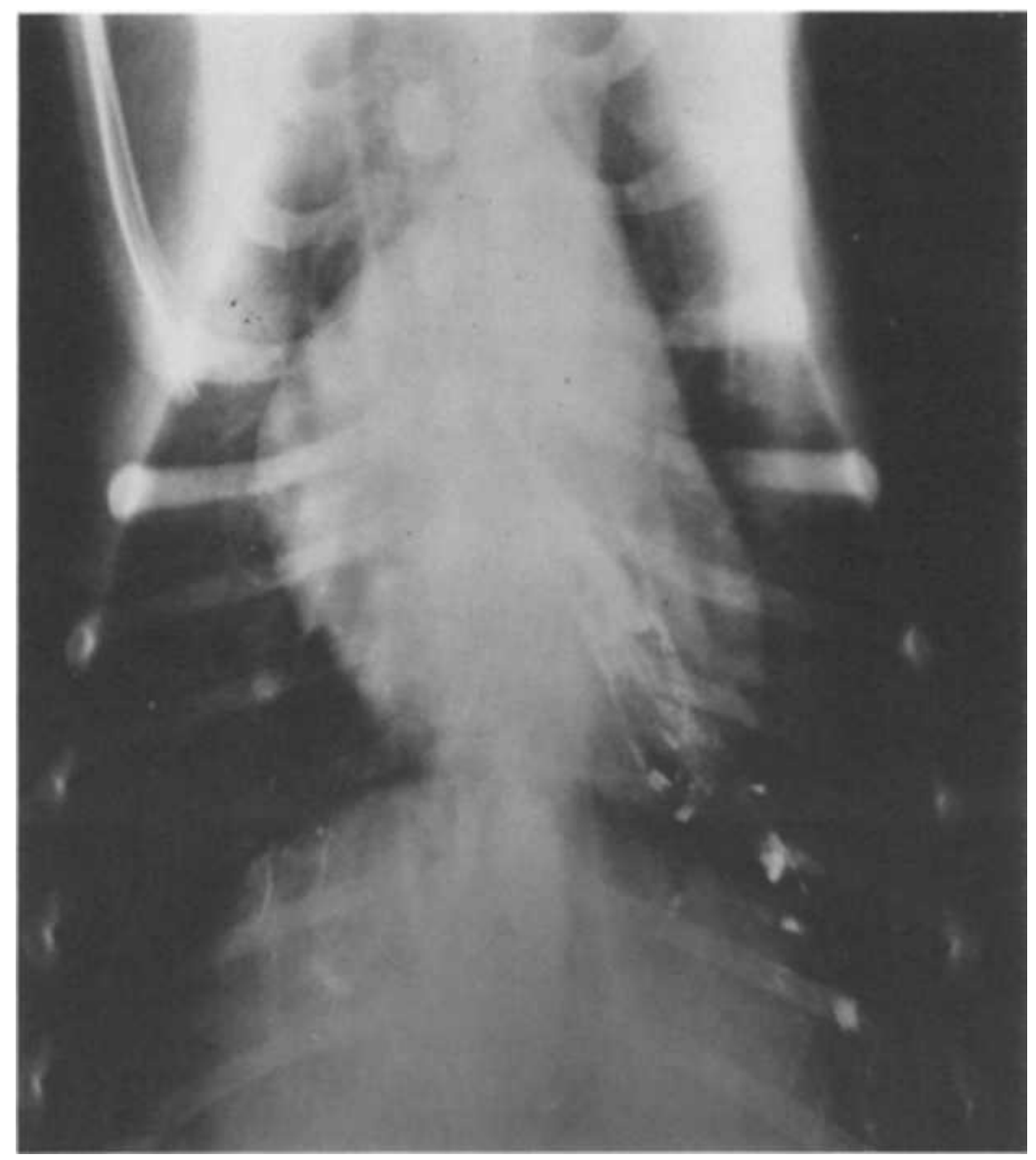

Figure 3c. At 4 hours there has been little further clearing. The relative delay on the left might be interpreted as the result of relatively greater trauma to that side during introduction of tantalum.

time that mucus can accumulate in alveolit ${ }^{10}$ but the mechanisms involved have not been described before.

Alveolarized mucus and tantalum are removed by the reticulo-endothelial system and deposited in peribronchial lymphatics and pulmonary lymph nodes. In dogs, tantalum which is deposited in the peribronchial lymphatics or draining lymph nodes may remain for many months - possibly indefinitely. Nothing is known about the long term effects of tantalum deposits in these areas and it is suggested that tantalum bronchography should be used with caution in humans.

In this study, puddling and alveolarization result in the deposition of tantalum in sites which are unaffected by ciliary clearance mechanisms. Only by disregarding puddling and alveolarization can normal clearance rates be determined. When isotopes are used to measure mucociliary clearance there is no means of identifying the location of the isotope in the lung, and puddling and alveolarization will not be recognized. Clearance rates, therefore, may appear abnormally long using isotope labels. 


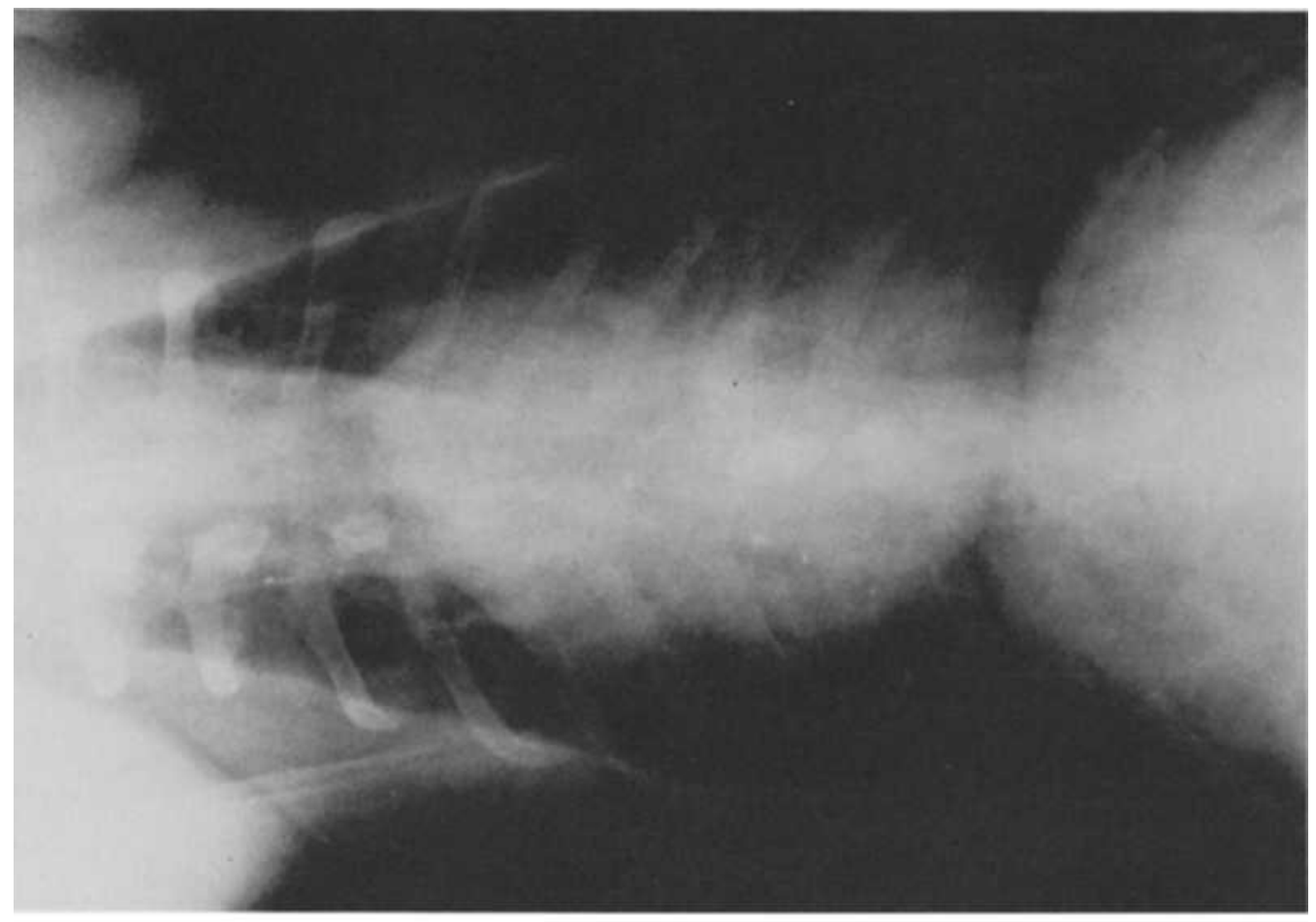




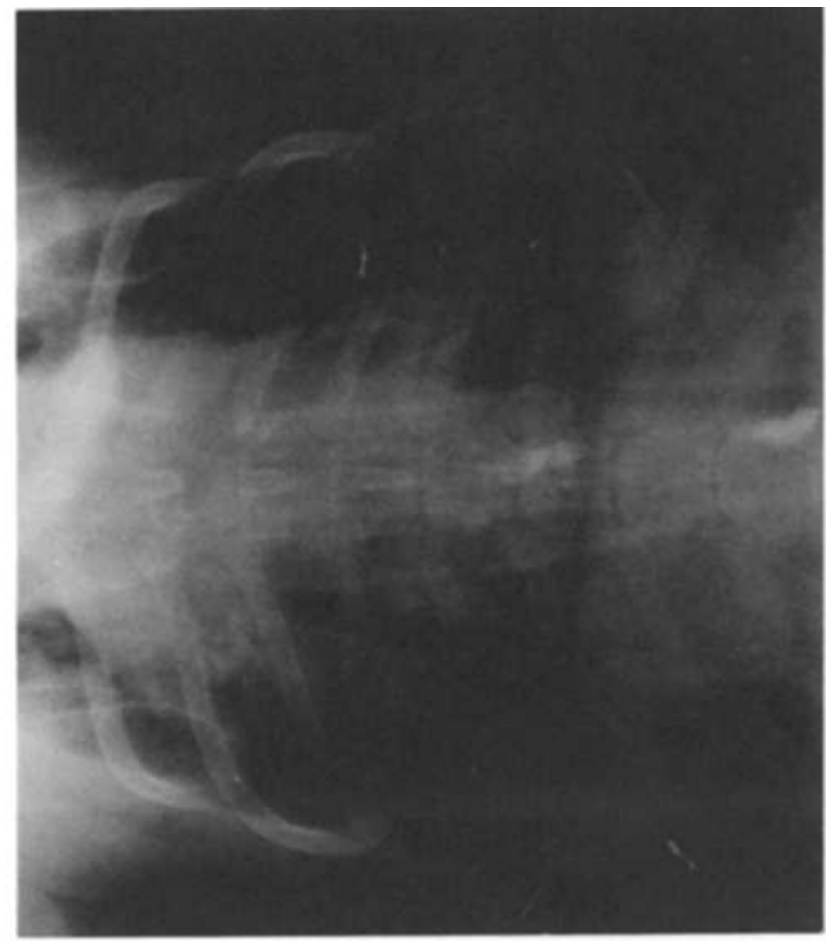

.3

氧

ڤั)

욤

몸. 해

bo.:

空

㕸

$\ddot{ت}$

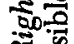

的

모ㅇㅠㅡㄹ

ํㅗำ

동

呵

宽苛

홍

명

ํํ용

䒓

톨

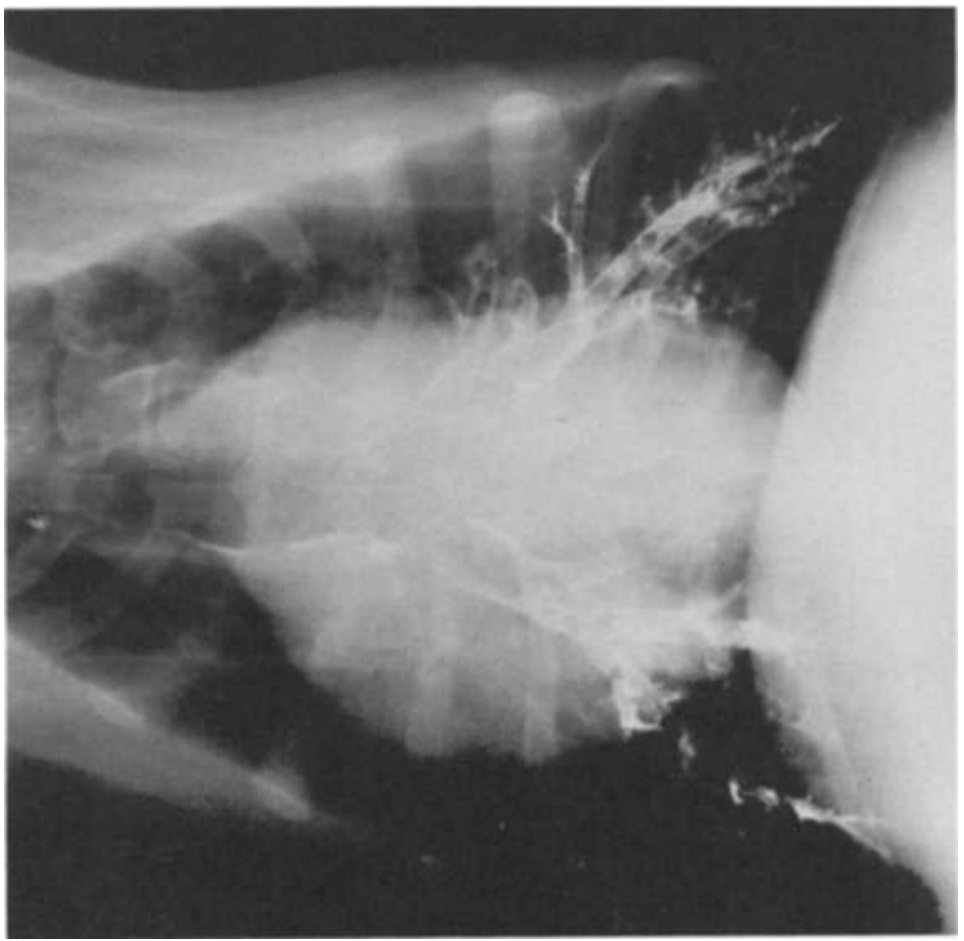

홍

疍

‡.

:

E

๘

की:

을

I

홍

苞

응

크

要寻

결

ఫ్

웅항

.

플

要

10.

돌

矛

点芯 

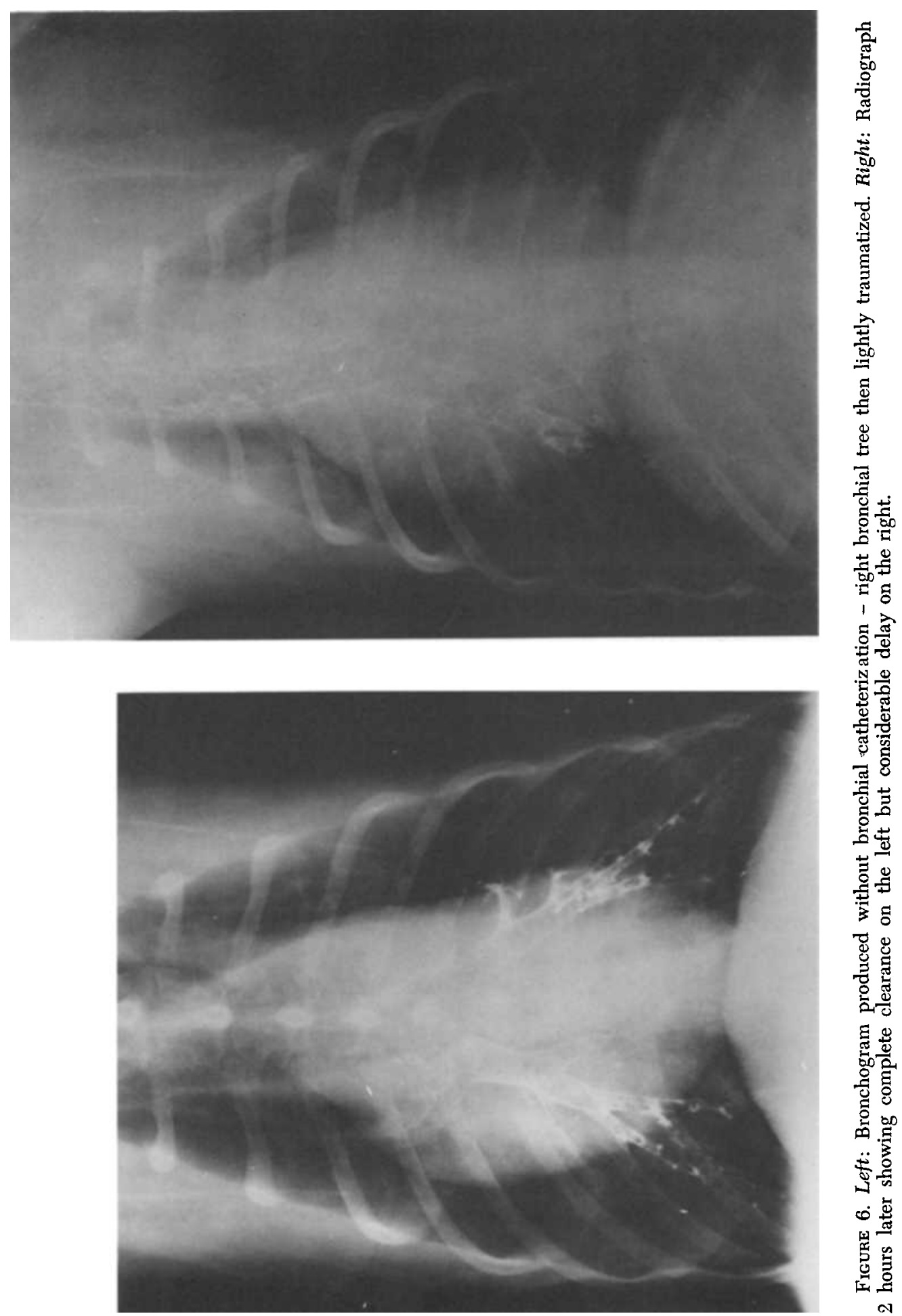
Summary AND Conclusions

Tantalum bronchography was used as a method of studying mucociliary clearance in normal dogs. The method originally described by Nadel was compared with a modification which obviates the trauma of endobronchial catheterization. In this modification tantalum was insufflated through an endotracheal tube or through a tracheal divider using a Harvard respirator.

The results show a considerably slower clearance of tantalum using Nadel's method of insufflation and it is suggested that this is due to the trauma of endobronchial catheterization.

In a third group of dogs bronchograms were produced using the modified technique. Then one side of the bronchial tree was lightly traumatized with an endobronchial catheter. Clearance was significantly slower on the traumatized side.

The study clearly demonstrates that mucosal trauma slows mucociliary clearance. This observation raises concern about possible adverse effects of such commonly used techniques as naso-tracheal or tracheostomy suction.

Gravitational pooling of mucus ("puddling") was noted in a number of instances during recovery from anaesthesia used for tantalum insufflation. Puddled mucus containing tantalum can lead to dispersal of tantalum in the alveoli (alveolarization), in which location there is no mucociliary apparatus and clearance occurs very slowly through the reticulo-endothelial system. If puddling occurred in humans it could produce atelectasis or disperse pathogenic organisms from more proximal parts of the bronchial tree to the periphery of the lung.

Alveolarized tantalum is deposited in the peribronchial lymphatics and lymph nodes where it may remain indefinitely. This observation warrants caution in the application of tantalum bronchography in humans.

If radioactive labels are used for clearance determinations, puddling and alveolarization will not be recognized when they occur and may lead to misleading clearance rates.

\section{RÉSUMÉ}

La bronchographie au tantalum a été utilisée comme méthode d'étude de la "clearance mucociliaire" chez des chiens normaux. La méthode originale décrite par Nadel a été comparée avec une modification de cette méthode qui élimine le traumatisme endobronchique du cathétérisme; cette modification a consisté à insuffler le tantalum à travers un tube endotrachéal ou à travers un diviseur de la trachée en employant un respirateur Harvard.

Les résultats démontrent que la clearance du tantalum est beaucoup plus lente si l'on emploie le méthode d'insufflation de Nadel et nous avons l'impression que cela serait dû au traumatisme du cathétérisme endobronchique.

Chez des chiens d'un troisième groupe, les bronchogrammes ont été faits en utilisant la technique modifiée. Alors sur un coté, l'arbre bronchique a été légèrement traumatisé par un cathétère endobronchique. La clearance a été plus lente sur le coté traumatisé et, cela, de façon significative.

L'étude démontre clairement que le traumatisme à la muqueuse ralentit la clearance mucociliaire. Cette observation fait naître des appréhensions sur les 
effets contraires ou indésirables de certaines techniques d'usage courant telles l'aspiration naso-trachéale ou l'aspiration des trachéostomies.

L'accumulation par gravité du mucus (puddling)a été observée chez un certain nombre de sujets au cours du réveil de l'anesthésie utilisée pour l'insufflation du tantalum. Le mucus accumulé qui contient du tantalum peut conduire à la dispersion du tantalum dans les alvéoles, (l'alvéolarisation) endroit où il n'existe pas d'appareil mucociliaire et la clearance se fait très lentement à l'aide du système réticulo-endothélial. Si l'accumulation survient chez les humains, elle peut conduire à l'atélectasie ou à la dispersion d'organismes pathogènes à partir des sites proximaux de larbre bronchique vers la périphérie du poumon.

Le tantalum alvéolarisé est déposé dans les lymphatiques et les ganglions péribronchiques où il peut séjourner indéfiniment. Cette observation constitue une mise en garde contre lutilisation de la bronchographie au tantalum chez les humains.

Si l'on utilise des marqueurs radioactifs pour évaluer la clearance, l'apparition de l'accumulation et de l'alvéolarisation ne peut pas être identifiée et cela peut conduire à des données de clearance erronnées.

\section{ACKNOWLEDGMENT}

We would like to thank R. Ilves, B.Sc., for his technical assistance.

\section{REFERENCES}

1. Dalmamn, T., Rylander, R., \& Spears, A.W. Differences in ciliotoxicity of cigarette smoke: comparison of two exposure methods. American Review of Respiratory Disease 96: 1078 ( 1967 ).

2. Togio, A., Imarisio, J.J., Murmall, H., \& Lepper, M.N. Clearance of large carbon particles from the human tracheobronchial tree. American Review of Respiratory Disease 87: 487 (1963).

3. Proctor, D.F., \& WAgner, H.N. Jr. Clearance of particles from the human nose. Archives of Environmental Health (Chicago) 11: 366 (1965).

4. Nadel, J.A., Wolfe, W.G., \& Graf, P.D. Powdered tantalum as a medium for bronchography in canine and human lungs. Investigative radiology 3: 299 (1968).

5. Nadel, J.A., Wolfe, W.G., Graf, P.D., Yonker, J.E., Zamel, N., Austin, J.H.M., HinchCliffe, W.A., Greenspan, R.H., \& Wright, R.R. Powdered tantalum a new contrast material for roentgenographic examination of human airways. New England Journal of Medicine 283: 281 ( 1970 ).

6. Edmunds, L.H. Jr., Graf, P.D., Sagel, S.S., \& Greenspan, R.H. Radiographic observations of clearance of tantalum and barium sulfate from airways. Investigative Radiology 5: $131(1970)$.

7. Hilding, A.C. \& Hilding, J.A. Tolerance of the respiratory mucous membrane to trauma. Annals of Otolaryngology $71: 455$ ( 1962 ).

8. RAHN, H. \& Ross, B.B. Bronchial tree casts, lobe wèights and anatomical dead space measurements in the dog lung. Journal of Applied Physiology 10: 154 (1956).

9. Parks, C.R., Woodrum, D.E., Graham, C.B., Cheney, F.W., \& Hodson, W.A. Effect of water nebulization on normal canine pulmonary mucociliary clearance. American Review of Respiratory Disease 104: 99 (1971).

10. McCarthy, C., Reid, L. \& Gibbons, R.A. Intraalveolar mucus-removal by macrophages: with iron accumulation. Journal of Pathology and Bacteriology 87: 39 (1964). 